\title{
Induced sputum: time from expectoration to processing
}

\author{
A. Efthimiadis, L. Jayaram, S. Weston, S. Carruthers, F.E. Hargreave
}

\begin{abstract}
Induced sputum: time from expectoration to processing. A. Efthimiadis, L. Jayaram, S. Weston, S. Carruthers, F.E. Hargreave. C) ERS Journals Ltd 2002.

ABSTRACT: One of the limitations in the use of induced sputum to measure indices of airway inflammation is the perceived need to process the sample within $2 \mathrm{~h}$. Therefore, the authors investigated whether the processing of induced sputum could be delayed.

Induced sputum samples obtained from asthmatic subjects $(n=30)$ were examined. Each sample was stored at 4 C. A portion was selected and processed within $2 \mathrm{~h}$ and the remaining expectorate (sputum plus saliva) was refrigerated. Later an equal amount was selected and processed at either $9(n=15)$ or $18(n=15) h$. The sputum was examined for cell counts and viability, fluid-phase eosinophil cationic protein (ECP), interleukin-8 (IL-8) and fibrinogen. Repeatability of measurements was assessed by the interclass correlation coefficient (ICC).

Measurements obtained at $9 \mathrm{~h}$ did not differ from those made at $2 \mathrm{~h}$ and the repeatability was excellent (ICC $0.88-0.99)$. However, by $18 \mathrm{~h}$ the median cell viability was reduced from $65.0 \%$ to $43.0 \%$ and the ICC was generally lower: 0.10 for total cell count, 0.24 for viability, 0.60 for neutrophils, 0.90 for eosinophils, 0.56 for macrophages, 0.76 for ECP, 0.82 for IL-8 and 0.84 for fibrinogen.

The results indicate that when induced sputum from subjects with asthma is kept at $4 \mathrm{C}$, examination of cell counts can be delayed for $\leqslant 9 \mathrm{~h}$ and for the fluid-phase indices measured for $\leqslant 18 \mathrm{~h}$. Further investigation of this issue is required for spontaneous sputum, other airway diseases and other inflammatory markers. Eur Respir J 2002; 19: 706-708.
\end{abstract}

Asthma Research Group, Firestone Institute for Respiratory Health, St Joseph's Healthcare and McMaster University, Hamilton, Ontario, Canada.

Correspondence: F.E. Hargreave, Firestone Institute for Respiratory Health, St. Joseph's Healthcare, 50 Charlton Ave. East, Hamilton, ON, Canada, L8N 4A6.

Fax: 19055216158

E-mail: hargreav@mcmaster.ca

Keywords: Induced sputum sputum cell counts sputum chemistry

Received: December 122000 Accepted after revision November 16 2001

This study was supported by a Medical School Grant from Merck Frosst Inc.
The value of sputum examination in research is established and there is increasing evidence that it might have a place in clinical practice [1]. One limitation of its use is the perceived need to process it within $2 \mathrm{~h}$ of collection. Sputum examination was therefore investigated in order to determine whether it could be delayed for longer without compromising the reproducibility of the total cell count, viability, eosinophils, neutrophils, macrophages and fluid-phase eosinophil cationic protein (ECP), interleukin (IL)-8 and fibrinogen.

\section{Methods}

\section{Subjects}

Subjects with asthma $(n=30)$ attended the Firestone Institute for Respiratory Health (table 1). The diagnosis of asthma was based on episodic symptoms of wheeze and dyspnoea with variable airflow limitation within the past year. The latter was indicated by an improvement in baseline forced expiratory volume in one second (FEV1) of $\geqslant 12 \% 10$ min after salbutamol $(200 \mu \mathrm{g})$ if the FEV1/slow vital capacity was $\geqslant 70 \%$, or by airway hyperresponsiveness to methacholine (expressed as the provocative concentration causing a $20 \%$ fall in FEV1 $\left(\mathrm{PC}_{20}\right)<8 \mathrm{mg} \cdot \mathrm{mL}^{-1}$ if it was $>70 \%$.
The study was approved by the hospital's Research Ethics Board.

\section{Study design}

An expectorate of sputum plus saliva was induced and stored at $4{ }^{\circ} \mathrm{C}$ until examined. One portion was selected and examined within $2 \mathrm{~h}$ and the remaining expectorate was coded and refrigerated at $4^{\circ} \mathrm{C}$. At $9 \mathrm{~h}$ in 15 subjects or $18 \mathrm{~h}$ in the other 15 , an equal amount was selected and examined. Examination of each sample was performed by one of two technologists blinded to each other, who had a high interobserver

Table 1. - Patient characteristics

Characteristics

Males $n$

$30 \pm 16$

Age yrs

$50 \pm 17$

Atopy $n$

FEV1 \% pred 12

PC20 methacholine $\mathrm{mg} \cdot \mathrm{mL}^{-1 \#} \quad 2.6 \pm 1.3$

Steroid use $n$

24

Data are presented as mean \pm SD unless otherwise stated. FEV1: forced expiratory volume in one second; $\mathrm{PC}_{20}$ : provocation concentration causing a $20 \%$ fall in FEV1; \% pred: $\%$ predicted. ${ }^{\#}$ : geometric mean \pm SD. 
Table 2. - Repeatability of sputum cell counts and fluid-phase measurements

\begin{tabular}{|c|c|c|c|c|c|c|}
\hline \multirow[t]{2}{*}{ Measurement } & \multicolumn{2}{|c|}{ Time points $(n=15)$} & \multirow[t]{2}{*}{ ICC } & \multicolumn{2}{|c|}{ Time points $(n=15)$} & \multirow[t]{2}{*}{ ICC } \\
\hline & $<2 \mathrm{~h}$ & $9 \mathrm{~h}$ & & $<2 \mathrm{~h}$ & $18 \mathrm{~h}$ & \\
\hline TCC $10^{6} \cdot \mathrm{g}^{-1}$ & $7.3(14.4)$ & $5.2(16.4)$ & 0.88 & $4.5(1.9)$ & $4.0(4.6)$ & 0.10 \\
\hline Viability \% & $71.0(20.0)$ & $69.0(29.0)$ & 0.89 & $65.0(25.0)$ & $43.0(36.0)$ & 0.24 \\
\hline Eosinophils \% & $1.8(7.0)$ & $2.0(8.5)$ & 0.94 & $1.8(4.9)$ & $1.3(2.7)$ & 0.90 \\
\hline Neutrophils \% & $47.7(36.0)$ & $41.0(30.0)$ & 0.95 & $41.0(35.8)$ & $52.7(12.2)$ & 0.60 \\
\hline Macrophages \% & $51.3(51.3)$ & $50.0(47.3)$ & 0.97 & $41.8(28.8)$ & $43.0(41.4)$ & 0.56 \\
\hline $\mathrm{ECP} \mu \mathrm{g} \cdot \mathrm{L}^{-1}$ & $1224(4984)$ & 953 (6161) & 0.93 & $1064(4820)$ & $1294(2634)$ & 0.76 \\
\hline IL-8 $\mathrm{pg} \cdot \mathrm{mL}^{-1}$ & $17696(53,674)$ & $17229(41081)$ & 0.89 & $18328(34436)$ & $14592(24096)$ & 0.82 \\
\hline Fibrinogen $\mathrm{ng} \cdot \mathrm{mL}^{-1}$ & $2740(13727)$ & $2069(14551)$ & 0.99 & $2410(12507)$ & $3110(9487)$ & 0.84 \\
\hline
\end{tabular}

Data are presented as median (interquartile range) unless otherwise stated. ICC: intraclass correlation coefficient; TCC: total cell count; ECP: eosinophil cationic protein; IL-8: interleukin-8.

repeatability of sputum cell counts [2]. Fluid-phase measurements were performed on coded samples by one observer.

\section{Sputum induction and examination}

Sputum was induced, selected and processed as described previously [3]. The total cell count and viability were obtained simultaneously in a modified Neubauer counting chamber (Hausser Scientific, Horsham, PA, USA). Cytospins were prepared, stained with Wright's and a 400 nonsquamous differential cell count was obtained. Cell morphology was assessed by grading preservation of the cell outline as described previously [3]. The change from the corresponding $<2$-h sample was determined by a score of zero and one for change and no change, respectively. The remaining cell suspension was centrifuged at $790 \times g$ for $4 \mathrm{~min}$ and the supernatant was aspirated and stored at $-70^{\circ} \mathrm{C}$ for later analysis of ECP, IL-8 and fibrinogen. The concentration of ECP $\left(\mu \mathrm{g} \cdot \mathrm{L}^{-1}\right)$ in the thawed supernatant was determined using a sensitive radioimmunoassay (Pharmacia and Upjohn, Uppsala, Sweden), IL-8 $\left(\mathrm{pg} \cdot \mathrm{mL}^{-1}\right)$ was determined by enzyme-linked immunosorbent assay (ELISA) (Amersham Pharmacia Biotech, Mississauga, $\mathrm{ON}$, Canada) and fibrinogen $\left(\mathrm{ng} \cdot \mathrm{mL}^{1}\right)$ was measured by a "sandwich" ELISA using a rabbit antihuman fibrinogen antibody (Dako A080; Dako Diagnostics, Mississauga, ON, Canada). The results were adjusted for dilution.

\section{Analysis}

Descriptive statistics were used to summarize clinical characteristics. PC20 data were log transformed and reported as geometric mean and geometric SD. The effect of time on the outcome measures was compared with a multivariate analysis of variance, and the source of significant variation was identified using Newman-Keuls post hoc analysis. Reliability of measurements was assessed by the intraclass correlation coefficient and, based on previous studies, values of $\geqslant 0.80$ were considered to be acceptable for cell counts [4].

\section{Results}

Measurements obtained at $9 \mathrm{~h}$ did not differ from those obtained at $2 \mathrm{~h}$ ( $\mathrm{p}>0.05$ for each comparison) (table 2). However, by $18 \mathrm{~h}$ there was a significant reduction in cell viability (median 71.0 versus 69.0 within 2-9 h compared with 65.0 versus 43.0 within 2-18 h), and post hoc analysis showed a significant difference between the $<2 \mathrm{~h}$ and $18 \mathrm{~h}$ samples $(\mathrm{p}<$ $0.001)$. There was also evidence of morphology changes due to lysis in $50 \%$ of the $18 \mathrm{~h}$ samples and one was uncountable.

Fluid-phase measurements of ECP, IL-8, and fibrinogen were not significantly different $(\mathrm{p}>0.05)$ between induced sputum processed within $2-9 \mathrm{~h}$ or those processed within 2-18 h (table 2).

\section{Discussion}

The results of this study suggest that the examination of induced sputum can be delayed for $\leqslant 9 \mathrm{~h}$, without altering the total cell count, viability, differential cell count and morphology. Fluid-phase ECP, IL-8 and fibrinogen may be delayed for $\leqslant 18 \mathrm{~h}$. These findings are relevant to laboratory logistics.

This is the first study to determine whether the repeatability of inflammatory cell counts and fluidphase measurements in induced sputum can be maintained for $>2 \mathrm{~h}$ when stored at $4^{\circ} \mathrm{C}$. The processing of sputum and examination of the cells is a lengthy process, which varies between $1-2 \mathrm{~h}$ based on the availability of automated staining methods and experienced personnel. The current $2 \mathrm{~h}$ time constraint between expectoration and processing places a limitation on the number of samples that can be processed in parallel and restricts the use of the method outside of research centres. The decision to refrigerate and examine cells at 9 and $18 \mathrm{~h}$ was for practical reasons. Refrigeration is commonly used to store biological fluids pending analysis, and studies in blood have confirmed that it improves the stability of the differential cell count compared to storage at room temperature [5]. A previous in-house pilot study (unpublished data) suggested that refrigeration of the entire expectorate for $7 \mathrm{~h}$ did not have an adverse affect on cell counts and morphology, while at $24 \mathrm{~h}$ 
most of the cells were damaged and unrecognizable. Therefore, examination at $9 \mathrm{~h}$ was considered to be reasonable for a working day and at $18 \mathrm{~h}$ to facilitate morning examination of samples arriving in the laboratory in the late afternoon.

The study findings of excellent reproducibility of measurements at $9 \mathrm{~h}$ was associated with preserved cell viability and morphology and deterioration in the cell counts at $18 \mathrm{~h}$ was observed. Although the fluidphase measurements of eosinophil cationic protein, interleukin-8, and fibrinogen also changed at $18 \mathrm{~h}$ this was not as profound. It should be realized, however, that these results are limited to induced sputum stored at $4{ }^{\circ} \mathrm{C}$ from subjects with asthma. Further study is required for spontaneously expectorated sputum, other airway diseases and other indices of airway inflammation.

Acknowledgements. The authors thank the subjects who volunteered to help with the study, and M. Inman and M. Pizzichini for statistical advice.

\section{References}

1. Jayaram L, Parameswaran K, Sears MR, Hargreave FE. Induced sputum cell counts: their usefulness in clinical practice. Eur Respir J 2000; 16: 150-158.

2. Pizzichini E, Leff JA, Reiss TF, et al. Montelukast reduces airway eosinophilic inflammation in asthma: a randomized, controlled trial. Eur Respir J 1999; 14: $12-18$.

3. Pizzichini E, Pizzichini MMM, Efthimiadis A, Hargreave FE, Dolovich J. Measurement of inflammatory indices in induced sputum: effects of selection of sputum to minimize salivary contamination. Eur Respir J 1996; 9: 1174-1180.

4. Pizzichini E, Pizzichini MMM, Efthimiadis A, et al. Indices of airway inflammation in induced sputum: reproducibility and validity of cell and fluid phase measurements. Am J Respir Crit Care Med 1996; 154: 308-317.

5. Wood BL, Andrews J, Miller S, Sabath DE. Refrigerated storage improves the stability of the complete blood cell count and automated differential. Am J Clin Pathol 1999; 112: 687-695. 